\title{
Spectroscopic Signatures of Resonance Inhibition Reveal Differences in Donor-Bridge and Bridge-Acceptor Couplings
}

David A. Shultz, ${ }^{1 *}$ Martin L. Kirk, ${ }^{2 *}$ Jinyuan Zhang, ${ }^{1, a}$ Daniel E. Stasiw, ${ }^{1, b}$ Guangbin Wang, ${ }^{1, c}$ Jing Yang, ${ }^{2}$ Diana Habel-Rodriguez, ${ }^{2}$ Benjamin W. Stein, ${ }^{2, d}$ and Roger D. Sommer ${ }^{1}$

${ }^{1}$ Department of Chemistry, North Carolina State University, Raleigh, North Carolina 27695-8204.

${ }^{2}$ Department of Chemistry, The University of New Mexico, MSC03 2060, 1 University of New Mexico, Albuquerque, New Mexico 87131-0001.

Email: shultz@ncsu.edu; mkirk@unm.edu

${ }^{a}$ Current address: Beijing National Laboratory for Molecular Sciences, CAS Key Laboratory of Organic Solids, Institute of Chemistry, Chinese Academy of Sciences, Beijing 100190, China

${ }^{\text {bC }}$ urrent address: Cree, Inc., Research Triangle Park, NC

'Current address: CombiBlocks, San Diego, CA

${ }^{\mathrm{d} C}$ Current address: Los Alamos National Laboratory, Los Alamos, NM

\section{X-Ray Diffraction.}

Selected crystallographic data are shown in Table S1. Single crystals suitable for structure analysis were selected from the bulk and mounted on a MiTeGen mounts. Data were collected on a Bruker-Nonius X8 Kappa Apex-II diffractometer by $\omega$ and $\phi$ scans using Mo K $\alpha$ radiation $(\lambda=0.71073$ Å). Corrections for Lorentz and polarization effects, and absorption were made using SADABS. ${ }^{1}$ Structures were solved using direct methods and refined using full-matrix least squares (on $F^{2}$ ) using the SHELX ${ }^{2}$ software package. All non-hydrogen atoms were refined anisotropically. $\mathrm{H}$ atoms were added at calculated positions, with coordinates and $\mathrm{U}_{\text {iso }}$ values allowed to ride on the parent atom.

Both materials crystallized in space group $\mathrm{P}-1$ and have solvent present near the bridge-NNO junction. In the case of Compound 1-PhMe 2 the solvent is $n$-hexane. One arm of the $\mathrm{Tp}^{\mathrm{Cum}, \mathrm{Me}}$ ligand is disordered over two positions, but was effectively modeled with use of SAME/SADI restraints to a reasonable chemical model. Compound $\mathbf{1}-\mathbf{M e}_{2} \mathrm{Ph}$ co-crystallized with solvent that was best modeled by a disordered and partially occupied mixture of methanol and dichloromethane. The partially occupied methanol is positioned within hydrogen bond distance to the NNO oxygen, but was not allowed to refine. 
Table S1. Crystallographic Date for 1-Me $\mathrm{Mh}_{2} \mathrm{Phd}$ 1-PhMe

\begin{tabular}{|c|c|c|}
\hline Crystal Data & $1-\mathrm{Me}_{2} \mathbf{P h}$ & $1-\mathrm{PhMe}_{2}$ \\
\hline Identification code & rds377 & rds371 \\
\hline Chemical formula & $\mathrm{C}_{65} \mathrm{H}_{79.86} \mathrm{BCl}_{1.14} \mathrm{~N}_{8} \mathrm{O}_{4.43} \mathrm{Zn}$ & $\mathrm{C}_{70} \mathrm{H}_{91} \mathrm{BN}_{8} \mathrm{O}_{4} \mathrm{Zn}$ \\
\hline Formula weight $\mathrm{g} / \mathrm{mol}$ & 1160.67 & 1184.68 \\
\hline Temperature /K & $100(2)$ & $90(2)$ \\
\hline Crystal system & triclinic & Triclinic \\
\hline Space group & $\mathrm{P}-1$ & $\mathrm{P}-1$ \\
\hline$a / \AA$ & $13.7356(9)$ & $13.8728(4)$ \\
\hline b / & $14.3196(8)$ & $15.2034(5)$ \\
\hline$c / \AA$ & $16.8518(11)$ & $16.2677(5)$ \\
\hline$\alpha / /^{\circ}$ & $77.839(2)$ & $81.656(2)$ \\
\hline$\beta \rho^{\circ}$ & $82.276(2)$ & $77.474(2)$ \\
\hline$\gamma \quad \rho^{\circ}$ & $72.005(2)$ & $82.871(2)$ \\
\hline$V \AA^{3}$ & $3073.1(3)$ & $3298.68(18)$ \\
\hline$Z$ & 2 & 2 \\
\hline$\rho_{\text {calc }} \mathbf{g} / \mathrm{cm}^{3}$ & 1.254 & 1.193 \\
\hline$F(000)$ & 1231 & 1268 \\
\hline$\theta$ range $/^{\circ}$ & 1.78 to 30.56 & 1.76 to 25.09 \\
\hline Reflections collected & 118598 & 67891 \\
\hline Independent rfln & $18761[\mathrm{R}(\mathrm{int})=0.0458]$ & $11689[\mathrm{R}(\mathrm{int})=0.0529]$ \\
\hline Data / restr. / parms. & 18761 / 0 / 769 & 11689 / 222 / 861 \\
\hline Goodness-of-fit & 1.022 & 1.177 \\
\hline$R_{1}^{a}(\mathrm{I}>2 \sigma(\mathrm{I}))$ & 0.0393 & 0.0675 \\
\hline $\mathrm{wR}_{2}^{b}(\mathrm{I}>\mathbf{2 \sigma}(\mathrm{I}))$ & 0.0913 & 0.151 \\
\hline
\end{tabular}

\section{References}

1) Bruker-AXS Inc. ( 2014), Madison Wisconsin, USA.

2) Sheldrick, G. M. (2008). Acta Cryst. A64, 112-122.

3) Dolomanov, O.V.; Bourhis, L.J.; Gildea, R.J.; Howard, J.A.K.; Puschmann, H., OLEX2: A complete structure solution, refinement and analysis program (2009). J. Appl. Cryst., 42, 339-341.

Magnetic Susceptibility and Magnetization. Magnetic susceptibility measurements were collected on a Quantum Design MPMS-XL7 SQUID magnetometer with an applied field of 0.7 T. A crystalline sample ( 20 mg) was loaded into a gel cap/straw sample holder and mounted to the sample rod with Kapton tape for variable temperature measurements. Raw data were corrected with Pascal's constants as a first approximation for molecular diamagnetism followed by a straight line correction to all data for diamagnetic response of sample container where the slope of the line represents the residual diamagnetic correction. The Magnetic susceptibility data were fit using a field-independent 
van Vleck expression, $\chi$ eff $\mathrm{T}=[\chi /(1-\theta \chi)] \mathrm{T}$, where $\theta=\frac{2 z J_{\text {inter }}^{\prime}}{N g^{2} \beta^{2}}$, and $\chi=\frac{0.75 g^{2}}{3+\exp \left(\frac{-2 J_{S Q B N N}}{0.695 \cdot T}\right)}$, and $\boldsymbol{J}_{\text {SQNN }}$ is the SQ-Bridge-NN magnetic exchange parameter. ${ }^{1}$ The origin of $z J_{\text {inter }}$ may be zero-field splitting, intermolecular interactions, saturation effects, or some combination of all three. ${ }^{1-2}$ In our data, the

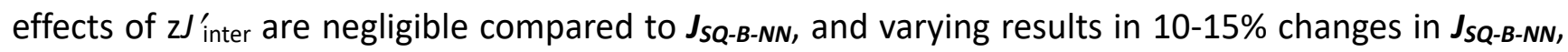
which is insufficient to alter either our discussion or conclusions. In fact, by omitting the $\chi_{\text {para }} \bullet T$ data points below $10 \mathrm{~K}$, the data can be fit adequately without the $\mathrm{J}^{\prime}$ inter term. Typically, the small deviation of the $g$-values (as a fit parameter) from the expected spin-only value of $\sim 2.00$ can be the result of minute ( $1 \%)$ weighing errors. We note that excellent fits required no "J-strain," suggesting that thermal (de)population of vibrational/torsional levels have no effect on the magnetic data, in accord with our published results on other SQ-Bridge-NN molecules.

Magnetization data (Fig. S1) were collected from the same samples as the magnetic susceptibility (see text Fig. 3), and the former data were collected at $2 \mathrm{~K}$ with applied magnetic fields of 0 to $7 \mathrm{~T}$.

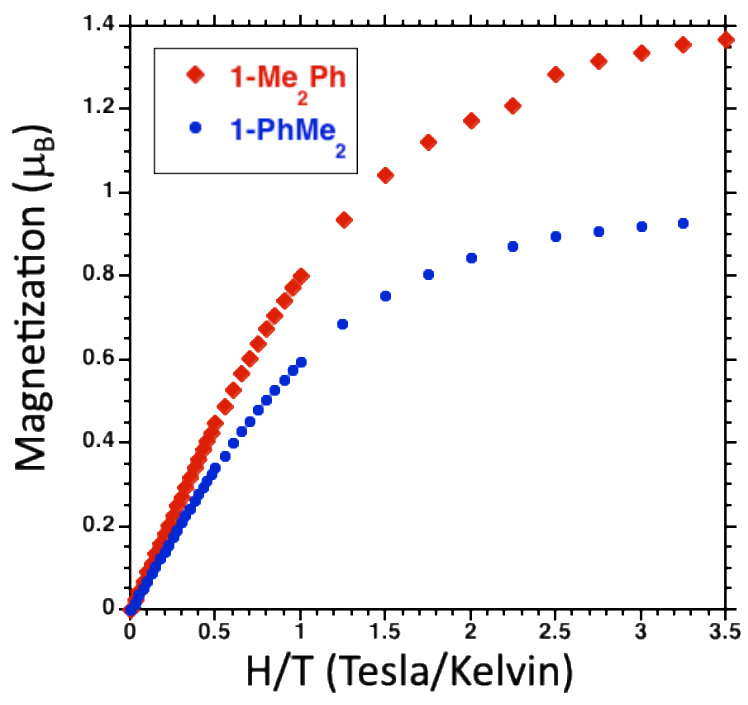

Figure S1. Magnetization plots for Complexes 1-Me ${ }_{2} \mathrm{Ph}$ and 1-PhMe $\mathbf{M}_{2}$ collected at 2 Kelvin. Saturation values for 1- $\mathrm{Me}_{2} \mathrm{Ph}$ and $1-\mathrm{PhMe}_{2}$ are $82 \%$ and $56 \%$ the theoretical value, respectively, due to diamagnetic impurities, and in the case of 1-PhMe $\mathrm{P}_{2}$ combined weak ferromagnetic coupling and antiferromagnetic $\mathrm{zJ}$ 'inter.

Table S2. Root mean square for the difference between calculated- and experimental $J_{S Q-B-N N}$ vs. CASSCF surface (see Fig. 4 in text).

\begin{tabular}{|c|c|c|c|c|c|c|c|c|c|c|}
\hline \multicolumn{8}{|c|}{ Experimental } & \multicolumn{3}{|c|}{ Calculated from Surface } \\
\hline & & & $x$ & & & $y$ & z & $\begin{array}{l}z=0.3415+(3 . \\
R^{2}=0.9992\end{array}$ & $(13.37 y)+(1$ & •y)+16.32y \\
\hline Complex & $\phi(\mathrm{SQ}) /^{\circ}$ & $\cos (\mathrm{SQ})$ & $\cos ^{2}(\mathrm{SQ})$ & $\phi(N N) /^{\circ}$ & $\cos (\mathrm{NN})$ & $\cos ^{2}(N N)$ & $\mathrm{J}_{\mathrm{ex}} / \mathrm{cm}^{-1}$ & $\mathrm{~J}_{\text {calc }} / \mathrm{cm}^{-1}$ & $\left|J_{\text {calc }} \mathrm{J}_{\mathrm{ex}}\right|$ & $\left|J_{\text {calc }^{-}} J_{\text {ex }}\right|^{2}$ \\
\hline 1-Ph & 33.9 & 0.830 & 0.689 & 12.65 & 0.976 & 0.952 & 100 & 122.5 & 22.5 & 507.99 \\
\hline 1-MePh & 48.40 & 0.664 & 0.441 & 14.09 & 0.970 & 0.941 & 81 & 78.20 & 2.80 & 7.85 \\
\hline 1-PhMe & 29.39 & 0.871 & 0.759 & 45.53 & 0.701 & 0.491 & 71 & 67.34 & 3.66 & 13.41 \\
\hline
\end{tabular}




\begin{tabular}{|c|c|c|c|c|c|c|c|c|c|c|}
\hline 1-Xylyl & 45.62 & 0.699 & 0.489 & 61.91 & 0.471 & 0.222 & 36 & 19.46 & 16.54 & 273.5 \\
\hline $1-\mathrm{Me}_{2} \mathrm{PhMe}_{2}$ & 83.60 & 0.112 & 0.012 & 68.89 & 0.360 & 0.130 & 2 & -0.78 & 2.78 & 7.72 \\
\hline 1-PhMe 2 & 48.05 & 0.668 & 0.447 & 68.98 & 0.359 & 0.129 & 27 & 10.08 & 16.92 & 286.2 \\
\hline $1-\mathrm{Me}_{2} \mathrm{Ph}$ & 95.12 & -0.089 & 0.008 & 33.25 & 0.836 & 0.699 & 2 & -0.81 & 2.81 & 7.92 \\
\hline \multicolumn{11}{|c|}{ Average $\left|J_{\text {calc }}-J_{\text {ex }}\right|^{2}=157.8$} \\
\hline \multicolumn{11}{|c|}{ RMS: Sqrt(Average $\left.\left|\mathrm{J}_{\text {calc }} \mathrm{J}_{\mathrm{ex}}\right|^{2}\right)=12.56$} \\
\hline \multicolumn{11}{|c|}{ Standard deviation $=13.57$} \\
\hline
\end{tabular}

RMS generally over-estimates the error in how well data fits to a model.

Resonance Raman Spectroscopy. Solid state resonance Raman spectra were collected in either a $180^{\circ}$ backscattering $(780 \mathrm{~nm})$ or $90^{\circ}$ scattering geometry. Raman data using $780 \mathrm{~nm}$ excitation rR collection were collected on a DXR Smart Raman Instrument (Thermo Fisher Scientific Inc) with 140 mW power. For other excitation wavelengths $(407,458,488,514$, and $633 \mathrm{~nm})$, Coherent Innova $70 \mathrm{C}(5 \mathrm{~W}) \mathrm{Ar}^{+}$ and $300 \mathrm{C}(1 \mathrm{~W}) \mathrm{Kr}^{+}$ion lasers were used as the photon sources. The scattered radiation was passed through a longpass filter (Semrock RazorEdge) to remove Rayleigh scattered laser light and then dispersed onto a liquid nitrogen cooled Infrared Associates CCD detector using a Princeton Acton spectrograph. The laser power at the sample was kept between 40 and $100 \mathrm{~mW}$ in order to prevent possible photo- and thermal degradation of the sample. Solid samples were prepared as finely ground powders and dispersed in a $\mathrm{NaCl}$ matrix with $\mathrm{Na}_{2} \mathrm{SO}_{4}$ added as an internal standard. These samples were subsequently sealed in a glass capillary tube and spun with a custom-made sample holder or thinly spread on carbon tape and held in a standard brass holder $(780 \mathrm{~nm})$. The construction of resonance Raman profiles was accomplished by comparing the integrated intensity of a Raman band at a given excitation wavelength relative to that of the $992.4 \mathrm{~cm}^{-1}$ band of $\mathrm{Na}_{2} \mathrm{SO}_{4}$. All data were scan-averaged, and any individual data set with vibrational bands compromised by cosmic events was discarded.

Computational Details. Spin-unrestricted gas-phase geometry optimization, Raman frequency, and excited state computations were performed at the density functional theory (DFT) level using the Gaussian 09W package. ${ }^{1}$ The calculations presented here were performed on truncated SQ-B-NN

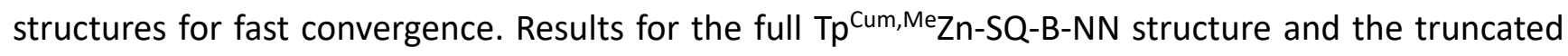
SQ-B-NN structure yielded very similar results. The B3LYP hybrid exchange-correlation functional and a 6-31g* basis set were used for all atoms. Time-dependent DFT (TDDFT) calculations were used to determine transition energies and assist in making band assignments. Computed Raman vibrations were generated using ChemCraft (version 1.7). ${ }^{2}$ See Table S3 for 1-PhMe 2 -NNTDDFT results using the 


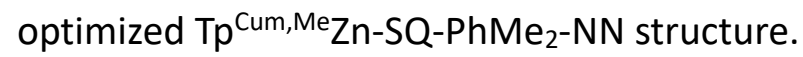

Computationally Assisted Band Assignments for 1-PhMe $-\mathrm{NN}$

\begin{tabular}{|c|c|c|c|c|c|}
\hline \multicolumn{6}{|c|}{ Table S3 } \\
\hline Band & $\begin{array}{c}\text { Computed } \\
\text { Excited State }\end{array}$ & Transition & $\begin{array}{l}\text { Dominant } \\
\text { One-Electron } \\
\text { Contributions }\end{array}$ & Energy (eV) & $\begin{array}{l}\text { Oscillator } \\
\text { Strength }(f)\end{array}$ \\
\hline A & 1 & 1 & $\begin{array}{l}\beta S Q(\mathrm{H} 0) \rightarrow \beta S Q(\mathrm{LO}) \\
{[81 \%]}\end{array}$ & 1.7087 & 0.0159 \\
\hline \multirow[t]{2}{*}{ B } & 5 & 2 & $\begin{array}{l}\beta N N(H 0) \rightarrow \beta N N(L 0) \\
{[32 \%]+} \\
\beta S Q(H 0) \rightarrow \beta N N(L 0) \\
{[13 \%]}\end{array}$ & 2.5278 & 0.0072 \\
\hline & 6 & 3 & $\beta T p \rightarrow \beta S Q(L 0)[68 \%]$ & 2.5285 & 0.0077 \\
\hline D & 7 & 4 & $\begin{array}{l}\beta N N(H 0) \rightarrow \beta S Q(L 0) \\
{[66 \%]}\end{array}$ & 2.5820 & 0.0415 \\
\hline \multirow[t]{4}{*}{$\mathbf{E}$} & 12 & 5 & $\begin{array}{l}\alpha S Q(H 0) \rightarrow a P h-N N(L 0) \\
{[52 \%]}\end{array}$ & 2.9869 & 0.0878 \\
\hline & 18 & 6 & $\beta T p \rightarrow \beta S Q(L 0)$ [46\%] & 3.2522 & 0.0391 \\
\hline & 19 & 7 & $\begin{array}{l}\beta P h-N N \rightarrow \beta S Q(L 0) \\
{[36 \%]+} \\
\alpha S Q(H 0) \rightarrow \alpha P h-N N(L 0) \\
{[16 \%]+\beta T p \rightarrow \beta S Q(L 0)} \\
{[15 \%]+\beta T p \rightarrow \beta S Q(L 0)} \\
{[12 \%]}\end{array}$ & 3.2918 & 0.1182 \\
\hline & 20 & 8 & $\begin{array}{l}\beta T p \rightarrow \beta S Q(L 0)[24 \%]+ \\
\beta S Q(o c c) \rightarrow \beta S Q(L 0) \\
{[22 \%]+\beta T p \rightarrow \beta S Q(L 0)} \\
{[17 \%]+\alpha S Q(H 0) \rightarrow} \\
\alpha P h-N N(L 0)[9 \%]\end{array}$ & 3.2992 & 0.0688 \\
\hline \multicolumn{6}{|c|}{$\begin{array}{l}\text { Notes: } \beta S Q(L 0) \text { is the hole counterpart to the } \alpha S Q(S 0) \text { singly occupied orbital. } \beta N N(L 0) \text { is the hole } \\
\text { counterpart to the } \alpha N N(S 0) \text { singly occupied orbital. } \alpha S Q(H O) \text { is the } S Q \text { singly occupied orbital. } \alpha N N(H 0) \\
\text { is the } N N \text { singly occupied orbital }\end{array}$} \\
\hline
\end{tabular}

\section{References}

1. Gaussian 09, R. A., M. J. Frisch, G. W. Trucks, H. B. Schlegel, G. E. Scuseria, M. A. Robb, J. R. Cheeseman, G. Scalmani, V. Barone, G. A. Petersson, H. Nakatsuji, X. Li, M. Caricato, A. Marenich, J. Bloino, B. G. Janesko, R. Gomperts, B. Mennucci, H. P. Hratchian, J. V. Ortiz, A. F. Izmaylov, J. L. Sonnenberg, D. Williams-Young, F. Ding, F. Lipparini, F. Egidi, J. Goings, B. Peng, A. Petrone, T. Henderson, D. Ranasinghe, V. G. Zakrzewski, J. Gao, N. Rega, G. Zheng, W. Liang, M. Hada, M. Ehara, K. Toyota, R. Fukuda, J. Hasegawa, M. Ishida, T. Nakajima, Y. Honda, O. Kitao, H. Nakai, T. Vreven, K. Throssell, J. A. Montgomery, Jr., J. E. Peralta, F. Ogliaro, M. Bearpark, J. J. Heyd, E. Brothers, K. N. Kudin, V. N. Staroverov, T. Keith, R. Kobayashi, J. Normand, K. Raghavachari, A. Rendell, J. C. Burant, S. S. Iyengar, J. 
Tomasi, M. Cossi, J. M. Millam, M. Klene, C. Adamo, R. Cammi, J. W. Ochterski, R. L. Martin, K. Morokuma, O. Farkas, J. B. Foresman, and D. J. Fox, Gaussian, Inc., Wallingford CT, 2016.

2. ChemCraft, available at http://www.chemcraftprog.com.

\section{Synthesis.}

General Considerations. Reagents and solvents were purchased from commercial sources and used as received unless otherwise noted. ${ }^{1} \mathrm{H}$ and ${ }^{13} \mathrm{C}$ NMR spectra were recorded on a Varian Mercury 400 $\mathrm{MHz}$ or a Varian Mercury $300 \mathrm{MHz}$ spectrometer at room temperature. ${ }^{1} \mathrm{H}$ and ${ }^{13} \mathrm{C}$ chemical shifts are listed in parts per million (ppm) and are referenced to residual protons or carbons of the deuterated solvents, respectively. EPR spectra were recorded on an IBM ER200D-SRC EPR spectrometer in $\mathrm{CH}_{2} \mathrm{Cl}_{2}$. Infrared spectra were recorded on a Brüker Vertex 80v spectrometer with Brüker Platinum ATR attachment. Mass spectra were obtained at the NCSU Mass Spectrometry Facility located in the Department of Chemistry. Compounds $1,{ }^{3} \mathbf{2 b},{ }^{2}$ 5-bromo-2-iodo-1,3-dimethylbenzene ${ }^{4}$ were prepared according to literature procedures. Aldehyde $\mathbf{2 a}$ was synthesized according to a modified procedure of Aguilar. ${ }^{5}$<smiles>Cc1cc(Br)cc(C)c1COc1cc(Br)cc(C)c1C(=O)O</smiles>

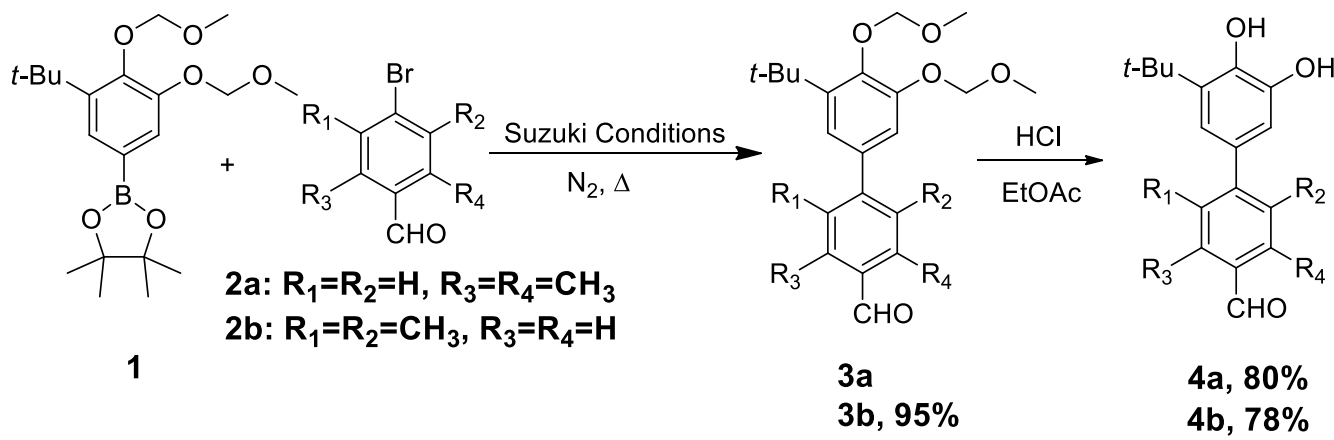

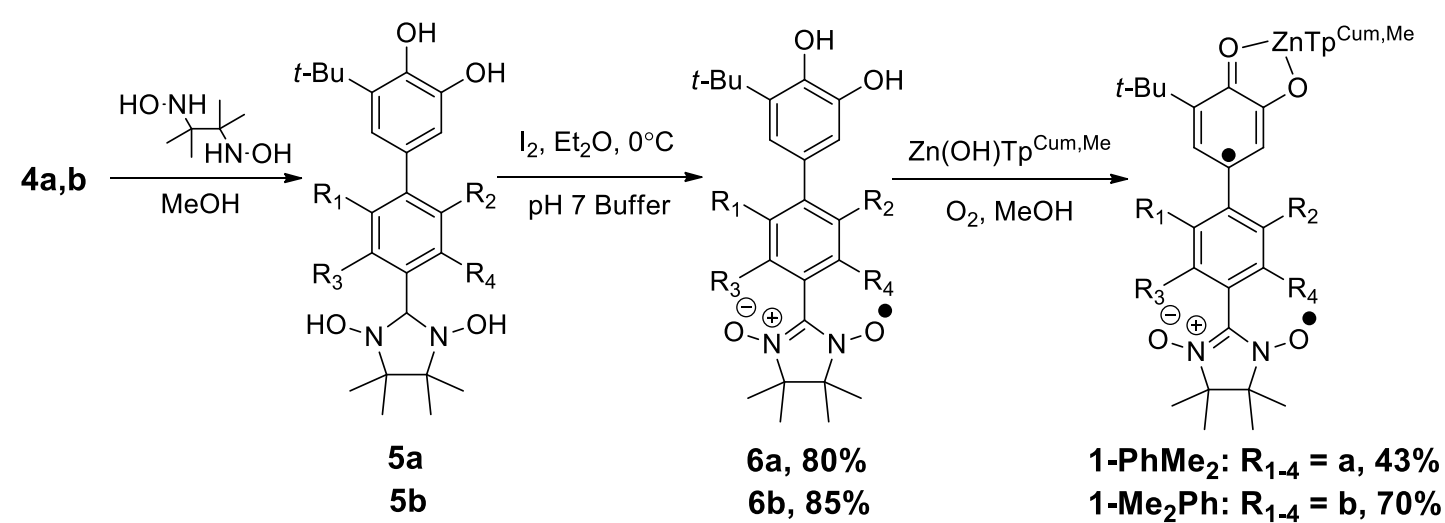


$100 \mathrm{~mL}$ Schlenk flask containing a stir bar were added $1.22 \mathrm{~g}(3.18 \mathrm{mmol})$ of 1 and $502 \mathrm{mg}(2.08$ $\mathrm{mmol})$ of $2 \mathrm{a}$. The flask was transferred to the glove box where $200 \mathrm{mg}(0.93 \mathrm{mmol})$ of $\mathrm{Pd}_{2}(\mathrm{dppf}) \mathrm{Cl}_{2}$ were added along with $20 \mathrm{~mL}$ dried THF. The Shlenk flask was transferred out and $2 \mathrm{~mL}(6.36 \mathrm{mmol})$ of degassed $2 \mathrm{M} \mathrm{K}_{2} \mathrm{CO}_{3}$ solution was added. The reaction flask was fit with a condenser under nitrogen and heated to reflux for $16 \mathrm{~h}$. The reaction mixture was then cooled, filtered into a separatory funnel and washed twice with $100 \mathrm{~mL}$ of sat'd $\mathrm{NaCl}$ solution. The organic layer was collected, dried with $\mathrm{Na}_{2} \mathrm{SO}_{4}$, and the solvent was removed under reduced pressure. The crude product was used in next step without further purification.

3'-(tert-butyl)-4',5'-dihydroxy-3,5-dimethyl-[1,1'-biphenyl]-4-carbaldehyde (4a). To a $100 \mathrm{~mL}$ round bottom flask was added $1.00 \mathrm{~g}(0.0 \mathrm{mmol}) 3 \mathrm{a}$ and $30 \mathrm{~mL}$ ethyl acetate. To the mixture was added $1 \mathrm{~mL}$ of $12 \mathrm{M} \mathrm{HCl}$ solution and this mixture was stirred for $2 \mathrm{~h}$. The reaction was quenched with $100 \mathrm{~mL}$ sat'd $\mathrm{NaHCO}_{3}$ solution and transferred to a separatory funnel. The organic layer was washed once with sat'd $\mathrm{NaHCO}_{3}$ solution and followed by another wash with sat'd $\mathrm{NaCl}$ solution. The organic layer was collected, dried with $\mathrm{Na}_{2} \mathrm{SO}_{4}$, filtered, and solvent was removed under reduced pressure. The crude product was purified by column chromatography $\left(\mathrm{SiO}_{2}, 15 \%\right.$ ethyl acetate in hexanes) to yield $3.2 \mathrm{~g}(85 \%)$ of compound 4a. ${ }^{1} \mathrm{H}$ NMR $(400 \mathrm{MHz}$, DMSO- $d 6, \delta): 10.50(\mathrm{~s}, 1 \mathrm{H}), 9.61(\mathrm{~s}, 1 \mathrm{H}), 8.38(\mathrm{~s}, 1 \mathrm{H})$, $7.28(\mathrm{~s}, 2 \mathrm{H}), 7.02(\mathrm{~d}, J=1.6 \mathrm{~Hz}, 1 \mathrm{H}), 6.99(\mathrm{~d}, J=1.6 \mathrm{~Hz}, 1 \mathrm{H}), 2.61(\mathrm{~s}, 6 \mathrm{H}), 1.39(\mathrm{~s}, 9 \mathrm{H}) .{ }^{13} \mathrm{C}$ NMR $(100$

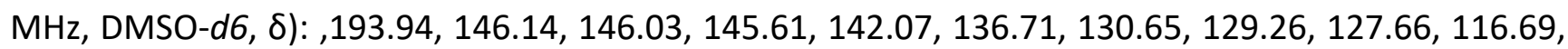
112.19, 35.16, 30.06, 21.02. IR (solid) $v_{\max }\left(\mathrm{cm}^{-1}\right)$ : 3111 (br, O-H), 1659 (s, C=O). Mass spectrometry (m/z): calculated for $\mathrm{C}_{19} \mathrm{H}_{22} \mathrm{O}_{3}(\mathrm{M}-\mathrm{H})^{-}:$:297.14962, found: $297.14953(\mathrm{M}-\mathrm{H})^{-}$.

2-(3'-(tert-butyl)-4',5'-dihydroxy-3,5-dimethyl-[1,1'-biphenyl]-4-yl)-4,4,5,5-tetramethylimidazolidine -1,3-diol (5a). To a $25 \mathrm{~mL}$ Schlenk flask were added $0.25 \mathrm{~g} 4 \mathrm{a}(0.84 \mathrm{mmol})$ and $0.24 \mathrm{~g}$ 2,3-dimethyl-2,3-bis(hydroxyamino)butane $(1.68 \mathrm{mmol}$ ). The flask was pump/purged three times and filled with $\mathrm{N}_{2}$. Anhydrous benzene $(10 \mathrm{~mL})$ was added to the reaction flask via syringe. The reaction flask was fit with a condenser under nitrogen and heated to reflux for $16 \mathrm{~h}$, followed by solvent removal under reduced pressure. The crude product 5a was collected and used for next step without further purification.

\section{2-(3'-(tert-Butyl)-4',5'-dihydroxy-3,5-dimethyl-[1,1'-biphenyl]-4-yl)-4,4,5,5,-tetramethyl-4,5-dihydroi} midazol-3-oxide-1-oxyl (6a). To a $100 \mathrm{~mL}$ round bottom flask, $0.66 \mathrm{~g}(1.52 \mathrm{mmol})$ of 5a was added with $60 \mathrm{~mL}$ diethyl ether, $40 \mathrm{~mL}$ buffer $(\mathrm{pH}=7)$, and then cooled to $0{ }^{\circ} \mathrm{C}$. To a $60 \mathrm{~mL}$ separatory funnel, $0.12 \mathrm{~g}$ ( $2.28 \mathrm{mmol}) \mathrm{I}_{2}$ was added with $30 \mathrm{~mL}$ diethyl ether and added dropwise to the stirring reaction mixture at $0{ }^{\circ} \mathrm{C}$. After all of the $I_{2}$ solution was added, the reaction was warmed to room temperature and transferred to a separatory funnel containing $100 \mathrm{~mL}$ buffer $(\mathrm{pH}=7)$. The organic layer was washed once with sat'd $\mathrm{Na}_{2} \mathrm{~S}_{2} \mathrm{O}_{3}$ solution followed by another wash of sat'd $\mathrm{NaCl}$ solution. The organic layer was dried over $\mathrm{Na}_{2} \mathrm{SO}_{4}$, filtered and the solvent removed under reduced pressure to yield $0.53 \mathrm{~g}(81 \%)$ of $6 \mathrm{a}$ as green solid. IR (solid) $v_{\max }\left(\mathrm{cm}^{-1}\right): 3305(\mathrm{br}, \mathrm{OH})$. EPR (X-Band, $\left.298 \mathrm{~K}\right): \mathrm{a}_{\mathrm{N}}=$ $7.35 \mathrm{G}(1: 2: 3: 2: 1)$. Mass spectrometry $(\mathrm{m} / \mathrm{z})$ : calculated for $\mathrm{C}_{25} \mathrm{H}_{33} \mathrm{~N}_{2} \mathrm{O}_{4}(\mathrm{M}-\mathrm{H})^{-:}: 424.23676$, found: $424.23719(\mathrm{M}-\mathrm{H})^{-}$. 


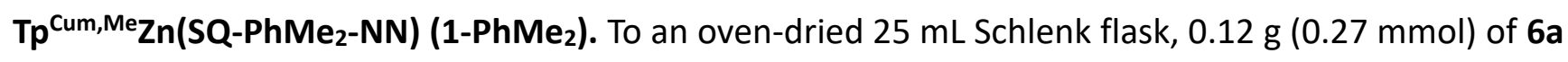
was added with $0.20 \mathrm{~g}(0.28 \mathrm{mmol})$ of $\mathrm{Tp}^{\mathrm{Cum}, \mathrm{Me}} \mathrm{Zn}(\mathrm{OH})$ and pump/purged with nitrogen three times. Anhydrous methanol $(15 \mathrm{~mL})$ and $2 \mathrm{~mL}$ dichloromethane were added to the Schlenk flask. The reaction was allowed to stir for $1 \mathrm{~h}$ under nitrogen then opened to air and stirred overnight. The solvent was removed under reduced pressure and the product purified by column chromatography (basic alumina, 30\% ethyl acetate in hexanes) to yield $0.13 \mathrm{~g}$ (43\%) of $\mathrm{Tp}^{\text {Cum,MeZn(SQ-PhMe }}{ }_{2}-\mathbf{N N}$ ). Crystals were grown from diffusion of hexane vapor into concentrated toluene solution. IR (solid) $v_{\max }$ $\left(\mathrm{cm}^{-1}\right)$ : $2544(\mathrm{w}, \mathrm{BH})$. EPR $\left(\sim 0.2 \mathrm{mM}\right.$ in $\left.\mathrm{CH}_{2} \mathrm{Cl}_{2}\right)$ : apparent $\mathrm{a}_{\mathrm{N}}=3.70 \mathrm{G}$. Mass spectrometry $(\mathrm{m} / \mathrm{z})$ : calculated for $\mathrm{C}_{64} \mathrm{H}_{77} \mathrm{~N}_{8} \mathrm{O}_{4} \mathrm{BZn}(\mathrm{M})^{+}$: 1096.54468, found: $1096.54636(\mathrm{M})^{+}$. Elemental analysis Calculated: (C: 69.67, H: 7.06, N: 10.20), Found: (C: 70.21, H: 7.12, N: 10.66).

3'-(tert-butyl)-4',5'-bis(methoxymethoxy)-2,6-dimethyl-[1,1'-biphenyl]-4-carbaldehyde (3b). To a $100 \mathrm{~mL}$ Schlenk flask were added $0.71 \mathrm{~g}(1.87 \mathrm{mmol})$ of $\mathbf{1}, 0.40 \mathrm{~g}(1.87 \mathrm{mmol})$ of $\mathbf{2 b}$, and transferred to the glove box where $0.10(0.12 \mathrm{mmol})$ of $\mathrm{Pd}_{2}(\mathrm{dppf}) \mathrm{Cl}_{2}$ were added with $20 \mathrm{~mL}$ dried THF. The Shlenk flask was transferred out of the glove box and $1.87 \mathrm{~mL}(3.74 \mathrm{mmol})$ of degassed $2 \mathrm{M} \mathrm{K}_{2} \mathrm{CO}_{3}$ solution were added, The reaction flask was fit with a condenser under nitrogen and heated to reflux for $16 \mathrm{~h}$. The reaction was then cooled, filtered into a separatory funnel, and washed twice with 100 $\mathrm{mL}$ of sat'd $\mathrm{NaCl}$ solution. The organic layer was collected and the solvent was removed under reduced pressure. The crude product was purified by column chromatography $\left(\mathrm{SiO}_{2}, 10 \%\right.$ ethyl acetate in hexanes) to yield $0.68 \mathrm{~g}(95 \%)$ of compound 3. ${ }^{1} \mathrm{H} \mathrm{NMR}\left(400 \mathrm{MHz}, \mathrm{CDCl}_{3}, \delta\right): 9.96(\mathrm{~s}, 1 \mathrm{H})$, $7.59(\mathrm{~s}, 2 \mathrm{H}), 6.79(\mathrm{~d}, J=2.0 \mathrm{~Hz}, 1 \mathrm{H}), 6.72(\mathrm{~d}, J=2.0 \mathrm{~Hz}, 1 \mathrm{H}), 5.26(\mathrm{~s}, 2 \mathrm{H}), 5.15(\mathrm{~s}, 2 \mathrm{H}), 3,67(\mathrm{~s}, 3 \mathrm{H}), 3.49$ (s, 3H), 2.11 (s, 6H), 1.43 (s, 9H). ${ }^{13} \mathrm{C} N M R\left(100 \mathrm{MHz}, \mathrm{CDCl}_{3}, \delta\right): 192.72,150.42,148.68,145.10$, 143.91, 137.69, 135.26, 134.76, 128.91, 120.76, 114.92, 99.26, 95.76, 57.79, 56.49, 35.50, 30.86, 21.13. IR (solid) $v_{\max }\left(\mathrm{cm}^{-1}\right): 1696(\mathrm{~s}, \mathrm{C}=\mathrm{O})$. Mass spectrometry $(\mathrm{m} / \mathrm{z})$ : calculated for $\mathrm{C}_{23} \mathrm{H}_{30} \mathrm{O}_{5}(\mathrm{M}+\mathrm{Na})^{+}$: 409.19855, found: $409.19858(\mathrm{M}+\mathrm{Na})^{+}$.

3'-(tert-butyl)-4',5'-dihydroxy-2,6-dimethyl-[1,1'-biphenyl]-4-carbaldehyde (4b). To a $100 \mathrm{~mL}$ round-bottom flask was added $0.68 \mathrm{~g}(1.78 \mathrm{mmol}) \mathbf{3 b}$ and $30 \mathrm{~mL}$ ethyl acetate. To this mixture was added $1 \mathrm{~mL}$ of $12 \mathrm{M} \mathrm{HCl}$ solution, and the reaction and was stirred for $30 \mathrm{~min}$. The reaction was quenched with $100 \mathrm{~mL}$ saturated $\mathrm{NaHCO}_{3}$ solution and transferred to a separatory funnel. The organic layer was washed once with sat'd $\mathrm{NaHCO}_{3}$ solution and followed by another wash with sat'd $\mathrm{NaCl}$ solution. The organic layer was collected and solvent was removed under reduced pressure. The crude product was purified by column chromatography $\left(\mathrm{SiO}_{2}, 30 \%\right.$ ethyl acetate in hexanes) to yield $0.51 \mathrm{~g}(75 \%)$ of compound 4b. ${ }^{1} \mathrm{H}$ NMR (400 MHz, DMSO-d6, $\left.\delta\right): 9.95(\mathrm{~s}, 1 \mathrm{H}), 9.48(\mathrm{~s}, 1 \mathrm{H}), 8.14(\mathrm{~s}, 1 \mathrm{H})$, $7.62(\mathrm{~s}, 2 \mathrm{H}), 6.44(\mathrm{~d}, J=1.2 \mathrm{~Hz}, 1 \mathrm{H}), 6.34(\mathrm{~d}, J=1.2 \mathrm{~Hz}, 1 \mathrm{H}), 2.08(\mathrm{~s}, 6 \mathrm{H}), 1.34(\mathrm{~s}, 9 \mathrm{H}) .{ }^{13} \mathrm{C}$ NMR $(100$ $\mathrm{MHz}$, DMSO-d6, $\delta):$ 193.60, 149.39, 145.73, 143.65, 137.67, 136.52, 135.20, 129.45, 129.02, 117.28, 113.35, 35.04, 30.12, 21.25. IR (solid) $v_{\max }\left(\mathrm{cm}^{-1}\right)$ : 3283 (br, O-H), 1687 (s, C=O). Mass spectrometry $(\mathrm{m} / \mathrm{z})$ : calculated for $\mathrm{C}_{19} \mathrm{H}_{22} \mathrm{O}_{3}(\mathrm{M}-\mathrm{H})^{-}: 297.14962$, found: $297.14957(\mathrm{M}-\mathrm{H})^{-}$. 
-1,3-diol (5b). To a $25 \mathrm{~mL}$ Schlenk flask were added $0.20 \mathrm{~g}$ compound $4 \mathrm{~b}(0.67 \mathrm{mmol})$ and $0.12 \mathrm{~g}$ 2,3-dimethyl-2,3-bis(hydroxyamino)butane $(0.81 \mathrm{mmol})$. The flask was pump purged three times and filled with $\mathrm{N}_{2}$. Then $6 \mathrm{~mL}$ anhydrous benzene was added to the reaction flask via syringe. The reaction flask was fit with a condenser under nitrogen and heated to reflux for $16 \mathrm{~h}$, followed by solvent removal under reduced pressure. The crude product 5 a was collected and used for the next step without further purification.

\section{2-(3'-(tert-Butyl)-4',5'-dihydroxy-2,6-dimethyl-[1,1'-biphenyl]-4-yl)-4,4,5,5,-tetramethyl-4,5-dihydroi} midazol-3-oxide-1-oxyl (6b). To a $100 \mathrm{~mL}$ round bottom flask, $0.29 \mathrm{~g}$ (0.67 mmol) of compound $5 \mathrm{~b}$ was added with $60 \mathrm{~mL}$ diethyl ether, $40 \mathrm{~mL}$ buffer $(\mathrm{pH}=7)$, and then cooled to $0{ }^{\circ} \mathrm{C}$. To a $60 \mathrm{~mL}$ separatory funnel, $0.12 \mathrm{~g}$ ( $2.28 \mathrm{mmol}) \mathrm{I}_{2}$ was added with $30 \mathrm{~mL}$ diethyl ether and added dropwise to the stirring reaction mixture at $0{ }^{\circ} \mathrm{C}$. After all of the $I_{2}$ was added, the reaction was warmed to room temperature and transferred to a separatory funnel containing $100 \mathrm{~mL}$ buffer $(\mathrm{pH}=7)$. The organic layer was washed once with sat'd $\mathrm{Na}_{2} \mathrm{~S}_{2} \mathrm{O}_{3}$ solution followed by another wash with sat'd $\mathrm{NaCl}$ solution. The organic layer was dried over $\mathrm{Na}_{2} \mathrm{SO}_{4}$, filtered, and the solvent removed under reduced pressure to yield $0.24 \mathrm{~g}(85 \%)$ of compound $\mathbf{6 b}$ as green solid. IR (solid) $v_{\max }\left(\mathrm{cm}^{-1}\right)$ : $3089(\mathrm{br}, \mathrm{OH})$. EPR (X-Band, $298 \mathrm{~K}): \mathrm{a}_{\mathrm{N}}=7.30 \mathrm{G}(1: 2: 3: 2: 1)$. Mass spectrometry $(\mathrm{m} / \mathrm{z})$ : calculated for $\mathrm{C}_{25} \mathrm{H}_{33} \mathrm{~N}_{2} \mathrm{O}_{4}(\mathrm{M}-\mathrm{H})^{-}: 424.23676$, found: $424.23657(\mathrm{M}-\mathrm{H})^{-}$. Elemental analysis Calculated: (C: 69.67, H: 7.06, N: 10.20), Found: (C: 70.13, H: 7.19, N: 10.58).

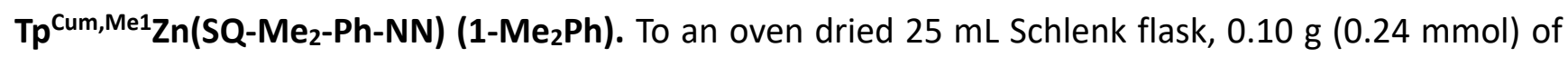
compound 6a was added with $0.20 \mathrm{~g}(0.28 \mathrm{mmol})$ of $\mathrm{Tp}^{\mathrm{Cum}, \mathrm{Me}} \mathrm{Zn}(\mathrm{OH})$ and pump/purged with nitrogen three times. Then $15 \mathrm{~mL}$ anhydrous methanol and $5 \mathrm{~mL}$ dichloromethane were added to the Schlenk flask. The reaction was allowed to stir for $1 \mathrm{~h}$ under nitrogen then opened to air and stirred overnight. The solvent was removed under reduced pressure and the product purified by column chromatography (basic alumina, $30 \%$ ethyl acetate in hexanes) to yield $0.18 \mathrm{~g}$ (70\%) of

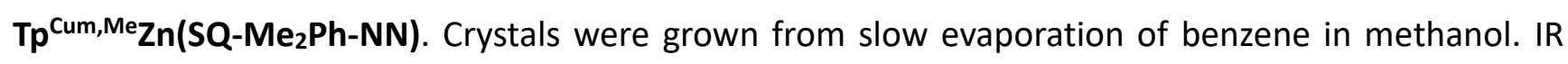
(solid) $v_{\max }\left(\mathrm{cm}^{-1}\right)$ : 2531 (w, BH). EPR $\left(\sim 0.2 \mathrm{mM}\right.$ in $\left.\mathrm{CH}_{2} \mathrm{Cl}_{2}\right)$ : apparent $\mathrm{a}_{\mathrm{N}}=3.65 \mathrm{G}$. Mass spectrometry $(\mathrm{m} / \mathrm{z})$ : calculated for $\mathrm{C}_{64} \mathrm{H}_{77} \mathrm{~N}_{8} \mathrm{O}_{4} \mathrm{BZn}(\mathrm{M}+\mathrm{H})^{+}:$: 1097.55251, found: $1097.55331(\mathrm{M}+\mathrm{H})^{+}$. Elemental analysis Calculated: (C: 69.67, H: 7.06, N: 10.20), Found: (C: 70.12, H: 7.12, N: 10.78).

\section{References}

1. Shultz, D. A.; Fico, R. M., Jr.; Bodnar, S. H.; Kumar, R. K.; Vostrikova, K. E.; Kampf, J. W.; Boyle, P. D., Trends in Exchange Coupling for Trimethylenemethane-Type Bis(Semiquinone) Biradicals and Correlation of Magnetic Exchange with Mixed Valency for Cross-Conjugated Systems. J. Am. Chem. Soc. 2003, 125, 11761.

2. Kang, B.; Kurutz, J. W.; Youm, K.-T.; Totten, R. K.; Hupp, J. T.; Nguyen, S. T., Catalytically active supramolecular porphyrin boxes: acceleration of the methanolysis of phosphate triesters via a combination of increased local nucleophilicity and reactant encapsulation. Chem. Sci. 2012, 3, 1938-1944.

3. Shultz, D. A.; Hollomon, M. G., Preparation and EPR Spectroscopic Investigation of Conjugated Oligomers Containing Semiquinone Repeat Units. Chem. Mater. 2000, 12, 580-585.

4. Li, B.; Chen, J.; Yuan, K.; Sun, T.; Zhuanli, F. 2012.

5. Aguilar, N.; Fernandez, J. C.; Terricabras, E.; Carceller, G. E.; Salas, S. J. Substituted tricyclic compounds with activity towards ep1 receptors. 2013. 